\title{
IDENTIFIKASI KOMPOSISI KIMIA TAR KAYU MAHONI UNTUK BIOFUEL PADA BERBAGAI TEMPERATUR PIROLISIS
}

\author{
Widya Wijayanti \\ Jurusan Teknik Mesin Universitas Brawijaya \\ Jalan MT. Haryono 167, Malang 65145, Indonesia \\ Telp. (0341) 587710, 587711 \\ E-mail: widya_dinata@ub.ac.id
}

\begin{abstract}
This study indentified the tar yield of pyrolysis of mahogany wood. The produced tar would be analyzed using GC-MS (Gas Chromatograph-Mass Spectrometry) to understand their chemical properties affected by temperature pyrolysis. It would be identified if the elements are flammable matters or not. It is due to the fact that the yields of pyrolysis desire the flammable matters as much as possible as a biofuel. The experiment was conducted at a fixed bed reactor. The needle particle of mahogany wood was used as the pyrolysis feedstock having weight of 200 gram, sizing of mesh $20 \mathrm{~nm}$, and containing 2\% moisture content. The variations of pyrolysis temperature influencing the mahogany wood decompositions are $250^{\circ} \mathrm{C}, 350^{\circ} \mathrm{C}, 450^{\circ} \mathrm{C}, 500^{\circ} \mathrm{C}$, $600^{\circ} \mathrm{C}, 700^{\circ} \mathrm{C}$ and $800^{\circ} \mathrm{C}$. The pyrolysis was carried out during 3 hours almost without Oxygen. The result of tar yields show that a getting higher of the pyrolysis temperature caused the volume and mass of tar formed by condensation in cold trap would increase up to $500^{\circ} \mathrm{C}$ and then decrease. The increasing of tar yields would also increase some acetic acid compounds and reach a peak at $350^{\circ} \mathrm{C}$ in which the acetic acid compound is a flammable substance. From the GC-MS results, it was also presented that at any pyrolysis temperatures, the amount of the flammable tar compounds were higher than the unflammable one. It can be interpreted that the tar yield is very potential as liquid fuel (bio-oil) because the main elements of tar is acetic acid having flash point (flash point) equal to $39^{\circ} \mathrm{C}$.
\end{abstract}

Keywords: chemical properties, tar yield, mahogany wood, biofuel, temperature

\section{PENDAHULUAN}

Kebutuhan bahan bakar minyak Indonesia dari tahun ke tahun terus mengalami peningkatan [1]. Permasalahannya, sumber bahan bakar minyak hasil bumi bersifat tidak dapat berkelanjutan (non renewable), sehingga perlu dicari dan dikembangkan bahan bakar alternatif yang hemat biaya dan ramah lingkungan. Dalam mengatasi kebutuhan energi bahan bakar, pemerintah mengeluarkan kebijakan energi nasional untuk pengembangan sumber energi alternatif pengganti minyak bumi melalui Peraturan Pemerintah Republik Indonesia No. 79 Tahun 2014.

Selain murah dan ramah lingkungan, biomassa merupakan salah satu sumber daya energi alternatif yang memiliki jumlah cadangan yang melimpah serta tersedia di dalam negeri biasanya berasal dari tanaman kehutanan atau pertanian [2]. Diprediksi pada tahun 2050, biomassa dapat memenuhi sekitar $38 \%$ kebutuhan bahan bakar langsung di dunia dan $17 \%$ dari sektor listrik. Mayoritas sumber energi biomasa terbesar diperoleh dari sisa limbah kayu yang mencapai 64\% [3].

Kayu mahoni (swietenia macrophylla king) merupakan salah satu bahan baku biomassa dimana dalam pemanfaatannya masih belum optimal dan tidak jarang masih menjadi limbah yang menumpuk seiring dengan pesatnya industri mebel atau furnitur. Oleh karena itu, limbah ini perlu dimanfaatkan sebagai bahan baku untuk memenuhi kebutuhan energi.

Kayu mahoni dipilih sebagai feedstock pirolisis, karena kayu mahoni terdiri atas senyawa kompleks dengan komposisi selulosa 35-50\%, hemiselulosa 20-30\%, dan lignin 25$30 \%$. Kayu mahoni sendiri termasuk hardword, yaitu jenis kayu yang keras yang memerlukan temperatur tinggi untuk mendekomposisi senyawa-senyawanya. Dalam proses pirolisis, outcome yang diperlukan adalah komposisi produk dari hasil proses (terutama hasil yang 
flammable) yang dipengaruhi oleh beberapa parameter, salah satunya temperatur. Oleh karena itu, penting untuk diteliti pada temperatur berapa senyawa-senyawa biomasa terdekomposisi dan bagaimana hasilnya yang menyangkut properties-nya. Dalam penelitian ini, hanya diamati hasil pirolisis yang berupa tar, sedangkan char dan gas tidak diamati.

Dalam pirolisis, hal yang paling mudah dilakukan adalah dengan mengamati dekompoisi senyawa homogen. Seperti yang dilakukan oleh [4,5] yang melihat proses pirolisis pada selulosa. Dari penelitian tersebut, akan diketahui berapa temperatur optimum untuk mengurai selulosa dan komposisi senyawa produk yang dihasilkan.

Tetapi, hal yang sulit dilakukan untuk mendekomposisi biomasa apabila senyawa biomasa yang terdiri atas beberapa senyawa kompleks. Hal ini dikarenakan, tiap-tiap senyawa mempunyai temperatur dekomposisi yang berbeda-beda. Sehingga, hasil produk tar yang dihasilkan pada berbagai temperature pirolisis juga akan mempunyai sifat kimia yang berbeda.

Alasan lain dipilinnya kayu mahoni adalah karena kayu ini merupakan salah satu jenis kayu hardwood popular di Indonesia, sehingga merupakan jenis kayu yang patut diulas dari segi potensi ilmiahnya. Kayu ini banyak dipakai dalam bidang furniture, sehingga dalam proses manufaktur, banyak sekali dihasilkan sampah produksi. Melalui penelitian ini, pirolisis merupakan salah satu metode konversi sampah kayu mahoni yang tepat untuk menjadi energi (tar), sehingga dapat mereduksi jumlah sampah organik.

Salah satu cara untuk mengubah biomasa menjadi sumber energi adalah dengan pirolisis. Pirolisis merupakan proses konversi energi yang sangat menjanjikan saat ini, sebagai precursor pada proses gasifikasi. Proses pirolisis sendiri merupakan proses dekomposisi thermal biomassa tanpa adanya oksigen. Di dalam furnace, Oksigen pada udara dihilangkan hingga mencapai kandungan maksimum $2 \%$, sehingga ikatan rantai panjang senyawa molekul hidrokarbon dalam kayu mahoni yang tadinya kompleks mengalami pemecahan ikatan menjadi ikatan molekul yang lebih sederhana dalam bentuk char(padat), tar (cair), dan gas [6] yang diperoleh dari proses dekomposisi komponen utama kayu yaitu selulosa, hemiselulosa dan lignin [7].

Banyak penelitian menunjukkan bahwa selulosa, hemiselulosa dan lignin menghasilkan senyawa tar yang berbeda-beda, tergantung bagaimana proses tersebut dilakukan. Lebih dari 400 senyawa yang telah teridentifikasi, dimana komponen senyawa tersebut ditemukan tergantung dari jenis kayu, umur tanaman sumber kayu, dan kondisi pertumbuhan kayu seperti iklim dan tanah [8]. Contohnya, tar yang dihasilkan dari selulosa adalah furan dan aldehida molekul kecil, tar yang dihasilkan dari hemiselulosa adalah asam asetat, dan yang dihasilkan dari lignin adalah furfural dan fenol [9].

Pada dasarnya, tar merupakan biomassa yang mengandung beberapa senyawa campuran komplek hidrokarbon. Semakin tinggi berat molekul hidrokarbon yang terkandung dalam tar, akan dibutuhkan energi/kalor yang besar untuk bisa terbakar. Hal ini tentu saja berbeda jika tar tersebut memiliki molekul hidrokarbon yang ringan, yang akan dengan mudah dimanfaatkan sebagai bahan bakar. Oleh karena itu, investigasi tentang senyawasenyawa yang dihasilkan dari produk pirolisis, khususnya tar perlu ditelaah lebih lanjut. Untuk menganalisis senyawa-senyawa hasil tar pada pirolisis, senyawa-senyawa tersebut dapat dikarakteristikkan berdasarkan sifat-sifat propertisnya. Seperti misalnya, sifat fisik tar yang mempunyai kemampuan untuk terbakar pada suhu tertentu. Sifat tar ini dapat dilihat dari sifat fisiknya melalui nilai titik nyalanya (flash point). Flash point sendiri merupakan temperatur terendah dimana senyawa/bahan yang dipanaskan mampu menghasilkan campuran uap yang cukup untuk membentuk campuran dengan udara dan dapat menyala ketika ada sumber api yang didekatkan [10]. Dari nilai flash point inilah senyawa/komponen tar dapat dibedakan menjadi senyawa yang mudah terbakar atau tidak. Senyawa/bahan bakar cair dinyatakan mudah terbakar apabila memiliki titik nyala kurang dari atau lebih dari $60^{\circ} \mathrm{C}$ dan dibawah $93^{\circ} \mathrm{C}[11]$.

Pada proses pirolisis, variasi temperatur merupakan salah satu parameter penting untuk dikaji karena menyangkut kondisi terdekomposisinya senyawa-senyawa pada biomas. Salah satu contoh pengaruh temperatur adalah dihasilkannya senyawa 
polisiklik aromatik hidrokarbon (PAH) pada temperatur di atas $700^{\circ} \mathrm{C}$ [12].

Selain itu, senyawa dalam tar juga dikelompokkan berdasarkan banyaknya unsur karbon pada setiap perubahan temperatur. Dalam hal ini, setiap peningkatan temperatur diperkirakan akan mengakibatkan senyawa hidrokarbon akan terdekomposisi atau mengalami pemecahan rantai karbon dari molekul komplek menjadi molekul yang lebih sederhana. Karena molekul mengalami dekomposisi akibat meningkatnya temperatur, maka ikatan unsur karbon yang awalnya panjang akan terdekomposisi menjadi ikatan karbon yang lebih pendek. Selanjutnya, ikatan karbon yang pendek inilah nanti yang akan diidentifikasi apakah akan menghasilkan senyawa-senyawa hidrokarbon yang lebih mudah terbakar atau tidak, mengingat pada bahan bakar, senyawa pendek yang berwujud cair/gas lebih mudah terbakar dibandingkan dengan senyawa padat yang memiliki rantai panjang.

Untuk menganalisa senyawa-senyawa tar yang dihasilkan oleh pirolisis ini digunakan alat uji gas chromatography-mass spectra (GCMS). GC-MS yang akan menganalisa dan mengidentifikasi susunan kimianya. Adapun penjelasan data senyawa-senyawa GC-MS dapat dilakukan dengan cara mengelompokkan puncak kromatogram yang berubah pada setiap variasi temperatur.

Bila penelitian sebelumnya menjelaskan bagaimana slow pirolisis dari serbuk gergaji sengon akan menghasilkan tar atau bio-oil yang mengandung senyawa yang berguna sebagai biofuel [13], maka dalam pencarian dan pengembangan sumber energi bahan bakar alternatif tidak hanya terfokus pada satu jenis kayu saja, namun juga diperlukan suatu penelitian lain untuk mengetahui potensi senyawa yang dapat menghasilkan bahan bakar alternatif, yaitu salah satunya melakukan pirolisis menggunakan serbuk kayu mahoni seperti yang akan dilakukan dalam penelitian ini. Dengan memvariasikan pirolisis kayu mahoni ini pada berbagai derajat variasi temperatur, maka diharapkan senyawa kimia hasil tar pirolisis kayu mahoni ini nanti bisa didapatkan karakteristiknya, apakah senyawasenyawa tersebut mempunyai potensi sebagai bahan bakar atau tidak.

\section{METODOLOGI PENELITIAN}

Penelitian ini menggunakan pirolisis dengan model fixed bed pirolisis dengan menggunakan real pilot plant. Oleh karena itu, pirolisis akan dilakukan pada berbagai temperatur pemanasan yaitu sebesar $250^{\circ} \mathrm{C}$, $350^{\circ} \mathrm{C}, 400^{\circ} \mathrm{C}, 450^{\circ} \mathrm{C}, 500^{\circ} \mathrm{C}, 600^{\circ} \mathrm{C}, 700^{\circ} \mathrm{C}$ dan $800^{\circ} \mathrm{C}$. Dari proses pirolisis ini akan didapatkan volume tar selama proses pirolisis serta senyawa tar yang dihasilkan setelah proses pirolisis. Sebelum proses pirolisis, kayu mahoni seberat 200 gram dimasukkan ke dalam piroliser/furnace kemudian diproses dengan waktu pirolisis 3 jam.

Mula-mula, kotoran serbuk kayu mahoni dibersihkan. Setalh itu, serbuk kayu tersebut disaring dengan ukuran mesh $20 \mu \mathrm{m}$. Hasil penyaringan bertujuan untuk menyeragamkan ukuran serbuk kayu sehingga dapat dianggap homogeny. Kemudian serbuk kayu tersebut di oven dengan temperatur $100^{\circ} \mathrm{C}$ selama 3 jam untuk mengurangi kadar air hingga kayu mahoni mempunyai kandungan kadar air sekitar $0-2 \%$. Setelah itu. serbuk kayu ditimbang seberat 200 gram, selanjutnya dimasukkan ke dalam piroliser.Katup $\mathrm{N}_{2}$ dibuka untuk dialirkan ke dalam piroliser agar $\mathrm{O}_{2}$ di dalam pirolizer dapat terdorong keluar dan piroliser bebas dari $\mathrm{O}_{2}$. Setelah itu, thermocontroller diatur untuk dilakukan proses pirolisis dengan variasi temperatur pertama yaitu $250^{\circ} \mathrm{C}$ dan dilakukan proses pirolisis selama 3 jam. Setelah proses pirolisis selesai, volume tar diukur. Selanjutnya, proses pirolisis diulangi pada temperatur $350^{\circ} \mathrm{C}, 450^{\circ} \mathrm{C}, 500^{\circ} \mathrm{C}$, $600^{\circ} \mathrm{C}, 700^{\circ} \mathrm{C}$ dan $800^{\circ} \mathrm{C}$. Tar hasil pirolisis kemudian dianalisa kandungan senyawanya dengan menggunakan GC-MS.

GC-MS adalah alat untuk mengidentifikasi komponen-komponen penyusun senyawa atau alat yang digunakan untuk mengetahui chemical properties dari suatu senyawa. 


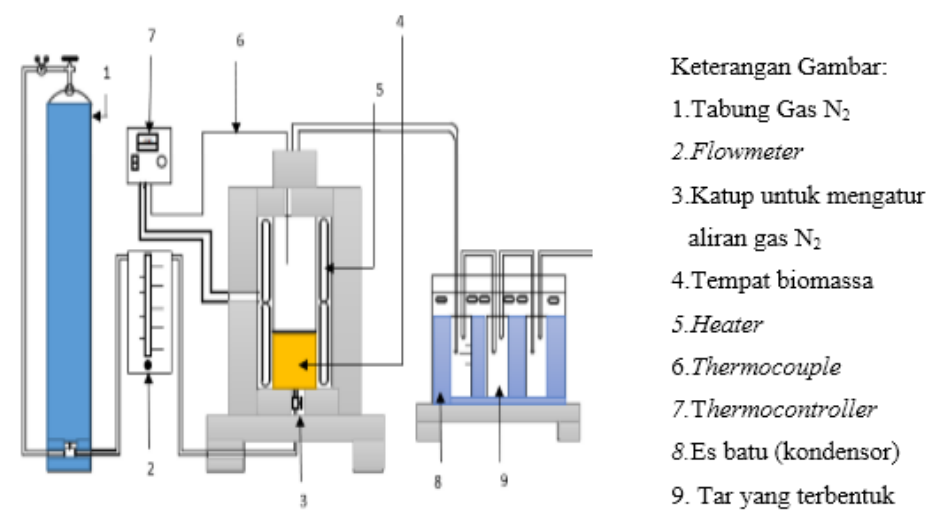

Gambar 1. Instalasi alat penelitian pirolisis

\section{HASIL DAN PEMBAHASAN}

Hasil penelitian ini berupa volume tar dan penjelasan propertis kimia tar pada temperatur $250^{\circ} \mathrm{C}, 350^{\circ} \mathrm{C}, 400^{\circ} \mathrm{C}, 450^{\circ} \mathrm{C}, 500^{\circ} \mathrm{C}, 600^{\circ} \mathrm{C}$, $700^{\circ} \mathrm{C}$ dan $800^{\circ} \mathrm{C}$. Sebagai contoh, analisa komposisi kimia hasil pirolisis yang berupa tar tersusun atas berbagai senyawa, seperti yang tertulis pada Tabel 1. Pada tabel tersebut, dituliskan senyawa-senyawa yang terdapat pada tar yang berpotensi sebagai biofuel pada temperatur pirolisis $500^{\circ} \mathrm{C}$.

Grafik hubungan antara variasi temperatur pirolisis dengan volume tar hasil pirolisis serbuk kayu mahoni dapat dilihat pada Gambar 2. Dari grafik dapat diketahui bahwa volume tar mengalami peningkatan dari temperatur $250^{\circ} \mathrm{C}$ sampai pada $500^{\circ} \mathrm{C}$ kemudian menurun sampai pada temperatur $800^{\circ} \mathrm{C}$.

Pada temperatur $250^{\circ} \mathrm{C}$, volume tar yang dihasilkan adalah sebesar $20 \mathrm{ml}$. Hal ini dikarenakan pada temperatur tersebut, kandungan hemiselulosa dan selulosa mulai terdekomposisi sebagian, sehingga volume tar yang dihasilkan hanya sebesar $20 \mathrm{ml}$. Pada temperatur yang cukup rendah ini, energi untuk mengurai senyawa-senyawa masih terlalu kecil, sehingga tidak cukup kuat untuk mongkonversi kayu menjadi fase cair.

Korelasi yang sama juga terjadi pada temperatur $350^{\circ} \mathrm{C}$. Pada temperatur ini, volume tar yang dihasilkan mengalami peningkatan dibanding temperatur $250^{\circ} \mathrm{C}$ yaitu menjadi sebesar $40 \mathrm{ml}$. Hal ini dikarenakan selain hemiselulosa dan selulosa sudah terdekomposisi, lignin sudah mulai terdekomposisi meskipun belum seluruhnya. Perlu dipahami bahwa hemiselulosa dan selulosa merupakan jaringan lunak pada kayu, sedangkan lignin merupakan jaringan yang cukup keras. Untuk mendekomposisi jaringan lunak, tidak diperlukan suhu yang tinggi, sebaliknya, untuk mengurai jaringan keras, dieprlukan energy yang besar. Oleh karena itu diperlukan suhu yang cukup tinggi bila ingin mengurai lignin.

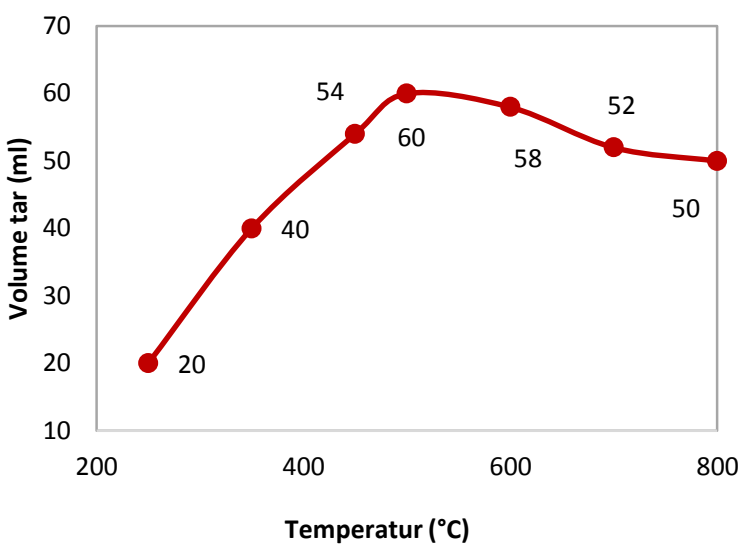

Gambar 2. Volume tar yang dihasilkan pada berbagai temperatur pirolisis

Selanjutnya, pada temperatur $450^{\circ} \mathrm{C}$, volume tar yang dihasilkan meningkat jika dibandingkan pada temperatur $250^{\circ} \mathrm{C}$ dan $350^{\circ} \mathrm{C}$ yaitu sebesar $54 \mathrm{ml}$. Hal ini dikarenakan energy pirolisis berupa kapasitas panas dari heater yang dipakai untuk mendekomposisi biomasa sudah cukup besar, sehingga hasil tar yang dihasilkan pun sudah meningkat.

Puncak hasil pirolisis tar terjadi pada temperatur $500^{\circ} \mathrm{C}$. Volume tar yang dihasilkan adalah sebesar $60 \mathrm{ml}$. Temepartur ini 
merupakan temperatur optimum apabila diinginkan produk pirolisis berupa tar. Hal ini dikarenakan setelah temperatur ini, kuantitas produk tar akan mengalami penurunan. Penurun produk ini diakibatkan produk lain pada proses pirolisis akan mengalami peningkatan. Produk pirolisis lain berupa gas mengalami peningkatan pada fase ini karena adanya secondary reaction pada proses pirolisis [14]. Pada fase tersebut, tar pada furnace yang belum sempat mengalami kondensasi pada kondensor, akan terurai menjadi gas.

Selanjutnya, untuk temperatur lebih dari $500^{\circ} \mathrm{C}$, volume tar hasil pirolisis serbuk kayu mahoni akan semakin menurun. Pada pada temperatur $600^{\circ} \mathrm{C}$ volume tar turun sebesar $2 \mathrm{ml}$ dan pada temperatur $700^{\circ} \mathrm{C}$ volume tar menurun lagi menjadi $52 \mathrm{ml}$. Sedangkan pada temperatur $800^{\circ} \mathrm{C}$ volume tar menurun sedikit menjadi 50 $\mathrm{ml}$. Hal ini dikarenakan adanya secondary reaction yan telah dijelaskan di atas, dimana reaksi ini menyebabkan gas yang dapat terkondensasi mengalami pemecahan molekulmolekul atau terdekomposisi menjadi molekul yang lebih kecil dan sederhana berupa gas yang tidak dapat terkondensasi seperti $\left(\mathrm{CO}, \mathrm{CO}_{2}, \mathrm{H}_{2}\right.$, $\mathrm{CH}_{4}$ ), sehingga hal ini menyebabkan volume tar hasil pirolisis serbuk kayu mahoni mengalami penurunan [15].

Selanjutnya, dari hasil analisa GC-MS didapatkan senyawa-senyawa yang terkandung pada tar pada berbagai temperatur. Pada penelitian ini didapatkan hasil uji GC-MS pada berbagai variasi temperatur pirolisis. Namun, sebagai contoh, ditunjukkan hasil uji properties pada temperatur $500^{\circ} \mathrm{C}$ saja yang dapat dilihat pada Tabel 1. Tabel ini menjelaskan chemical properties tar pada temperatur. Chemical properties disini menunjukkan kandungan komponen tar berikut rumus molekulnya (RM), besar prosentase senyawa, flash point, dan boiling point-nya. Setelah didapatkan chemical properties tar, karakterisasi tar berdasarkan sifatnya berupa flammable matter akan dipetakan pada grafik - grafik selanjutnya.

Grafik hubungan antara variasi temperatur pirolisis dengan kandungan asam asetat dapat dilihat pada Gambar 3. Dari grafik dapat diketahui bahwa kandungan asam asetat mengalami peningkatan dari temperatur $250^{\circ} \mathrm{C}$ sampai pada $350^{\circ} \mathrm{C}$ kemudian menurun sampai pada temperatur $800^{\circ} \mathrm{C}$. Mengapa asam asetat ini dipetakan pada grafik ini karena asam asetat merupakan bahan utama yang berpotensi sebagai biofuel.

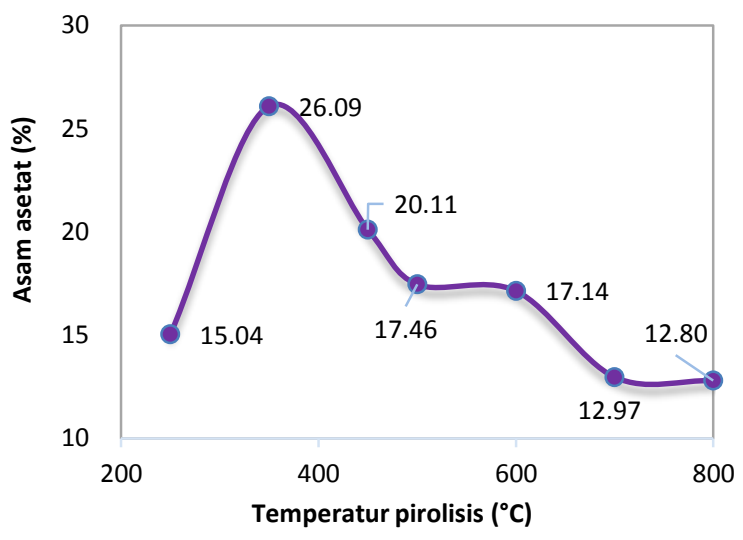

Gambar 3. Grafik pengaruh temperatur pirolisis terhadap presentase asam asetat

Pada temperatur $250^{\circ} \mathrm{C}$, kandungan asam asetat yang dihasilkan adalah sebesar $15.04 \%$. Hal ini dikarenakan pada temperatur tersebut, tidak cukup energy berupa panas yang dibutuhkan untuk mengurai senyawasenyawa penyusun kayu, sehingga kandungan asam asetat yang dihasilkan hanya sebesar $15.04 \%$.

Pada temperatur $350^{\circ} \mathrm{C}$ kandungan asam asetat yang dihasilkan yaitu sebesar $26.09 \%$. Hal ini dikarenakan dengan adanya penambahan suhu yang besar akan mempercepat reaksi dekomposisi. Pada temperatur $350^{\circ} \mathrm{C}$ dekomposisi senyawa biopolimer seperti hemiselulosa dan selulosa telah terdekomposisi seluruhnya. Sehingga kandungan asam asetat hasil pirolisis serbuk kayu mahoni pada temperatur $350^{\circ} \mathrm{C}$ menghasilkan jumlah yang paling besar. Lebih dari temperatur $350^{\circ} \mathrm{C}$, kandungan asam asetat hasil pirolisis serbuk kayu mahoni akan semakin menurun meskipun volume dan masa yang dihasilkan semakin besar, yaitu pada temperatur $450^{\circ} \mathrm{C}$ kandungan asam asetat sebesar $20.11 \%$, temperatur $500^{\circ} \mathrm{C}$ kandungan asam asetat sebesar $17.46 \%$, temperatur $600^{\circ} \mathrm{C}$ kandungan asam asetat sebesar17.14\%. Pada temperatur $700^{\circ} \mathrm{C}$ kandungan asam asetat sebesar $12.97 \%$, dan temperatur $800^{\circ} \mathrm{C}$ kandungan asam asetat sebesar $12.80 \%$. Pada temperatur $450^{\circ} \mathrm{C}$ dan $500^{\circ} \mathrm{C}$, prosentase asam asetat menunjukkan 
jumlah yang hampir sama. Hal ini dikarenakan dekomposisi senyawa biopolimer seperti hemiselulosa dan selulosa telah terdekomposisi seluruhnya pada temperatur $350^{\circ} \mathrm{C}$. Sehingga dengan penambahan suhu senyawa biopolimer seperti hemiselulosa dan selulosa hanya sedikit yang terdekomposisi, tetapi ligninlah yang mulai terdekomposisi [12].

Tabel 1.Contoh propertis tar pada temperatur pirolisis $500^{\circ} \mathrm{C}$ dengan GC-MS

\begin{tabular}{|c|c|c|c|c|}
\hline Komponen & RM & $\begin{array}{c}\text { Area } \\
(\%)\end{array}$ & $\begin{array}{l}\text { Flash } \\
\text { point }\end{array}$ & $\begin{array}{l}\text { Boiling } \\
\text { point }\end{array}$ \\
\hline methanamine & $\mathrm{CH}_{5} \mathrm{~N}$ & 4.80 & $-10^{\circ} \mathrm{C}$ & $\begin{array}{l}-6.6 \text { to } \\
-6.0^{\circ} \mathrm{C}\end{array}$ \\
\hline methanamine & $\mathrm{CH}_{5} \mathrm{~N}$ & 2.88 & $-10^{\circ} \mathrm{C}$ & $\begin{array}{l}-6.6 \text { to } \\
-6.0^{\circ} \mathrm{C}\end{array}$ \\
\hline $\begin{array}{l}\text { 2-pentanone } \\
\text { formic acid }\end{array}$ & $\begin{array}{l}\mathrm{C}_{5} \mathrm{H}_{10} \mathrm{O} \\
\mathrm{CH}_{2} \mathrm{O}_{2}\end{array}$ & $\begin{array}{l}0.80 \\
0.38\end{array}$ & $\begin{array}{l}7{ }^{\circ} \mathrm{C} \\
69^{\circ} \mathrm{C}\end{array}$ & $\begin{array}{c}102^{\circ} \mathrm{C} \\
100.8^{\circ} \mathrm{C}\end{array}$ \\
\hline acetid acid & $\mathrm{C}_{2} \mathrm{H}_{4} \mathrm{O}_{2}$ & 17.46 & $39^{\circ} \mathrm{C}$ & $\begin{array}{l}117.8^{\circ} \mathrm{C}- \\
118.8^{\circ} \mathrm{C}\end{array}$ \\
\hline 2-pentanol & $\mathrm{C}_{5} \mathrm{H}_{12} \mathrm{O}$ & 0.60 & $34{ }^{\circ} \mathrm{C}$ & $119.3^{\circ} \mathrm{C}$ \\
\hline $\begin{array}{l}\text { propanoic acid } \\
\text { pyridine }\end{array}$ & $\begin{array}{l}\mathrm{C}_{3} \mathrm{H}_{6} \mathrm{O}_{2} \\
\mathrm{C}_{5} \mathrm{H}_{5} \mathrm{~N}\end{array}$ & $\begin{array}{l}0.25 \\
0.37\end{array}$ & $\begin{array}{l}54^{\circ} \mathrm{C} \\
20^{\circ} \mathrm{C}\end{array}$ & $\begin{array}{l}141.15^{\circ} \mathrm{C} \\
96-98^{\circ} \mathrm{C}\end{array}$ \\
\hline $\begin{array}{l}\text { 3-butene-1,2- } \\
\text { diol } \\
2-\end{array}$ & $\mathrm{C}_{4} \mathrm{H}_{8} \mathrm{O}_{2}$ & 1.78 & $109^{\circ} \mathrm{C}$ & $196.5^{\circ} \mathrm{C}$ \\
\hline $\begin{array}{l}\text { furancarboxal } \\
\text { dehyde }\end{array}$ & $\mathrm{C}_{5} \mathrm{H}_{4} \mathrm{O}_{2}$ & 5.88 & $62{ }^{\circ} \mathrm{C}$ & $162{ }^{\circ} \mathrm{C}$ \\
\hline $\begin{array}{l}\text { pyridine, 2- } \\
\text { methyl- }\end{array}$ & $\mathrm{C}_{6} \mathrm{H}_{7} \mathrm{~N}$ & 0.21 & $29^{\circ} \mathrm{C}$ & $\begin{array}{l}128^{-} \\
129^{\circ} \mathrm{C}\end{array}$ \\
\hline $\begin{array}{l}\text { 2-cyclopenten- } \\
\text { 1-one }\end{array}$ & $\mathrm{C}_{5} \mathrm{H}_{6} \mathrm{O}$ & 1.16 & $42^{\circ} \mathrm{C}$ & $64-65^{\circ} \mathrm{C}$ \\
\hline $\begin{array}{c}\text { 2-pentanone, } \\
\text { 3-ethyl- }\end{array}$ & $\mathrm{C}_{7} \mathrm{H}_{14} \mathrm{O}$ & 0.81 & $31^{\circ} \mathrm{C}$ & $138.79^{\circ} \mathrm{C}$ \\
\hline $\begin{array}{c}2- \\
\text { furanmethanol }\end{array}$ & $\mathrm{C}_{5} \mathrm{H}_{6} \mathrm{O}_{2}$ & 1.07 & $65^{\circ} \mathrm{C}$ & $170^{\circ} \mathrm{C}$ \\
\hline $\begin{array}{l}\text { 2-propanone, } \\
\text { 1-(acetyloxy)- }\end{array}$ & $\mathrm{C}_{5} \mathrm{H}_{8} \mathrm{O}_{3}$ & 0.63 & $38^{\circ} \mathrm{C}$ & $174-176^{\circ}$ \\
\hline $\begin{array}{c}n, n- \\
\text { diethylformami } \\
\text { de }\end{array}$ & $\mathrm{C}_{5} \mathrm{H}_{11} \mathrm{NO}$ & 0.39 & $60^{\circ} \mathrm{C}$ & $\begin{array}{l}176- \\
177^{\circ} \mathrm{C}\end{array}$ \\
\hline $\begin{array}{c}2(5 \mathrm{H})- \\
\text { furanone } \\
2(3 \mathrm{H})-\end{array}$ & $\mathrm{C}_{4} \mathrm{H}_{4} \mathrm{O}_{2}$ & 2.58 & $101^{\circ} \mathrm{C}$ & $86-87^{\circ} \mathrm{C}$ \\
\hline $\begin{array}{l}\text { Furanone, 5- } \\
\text { methyl- }\end{array}$ & $\mathrm{C}_{5} \mathrm{H}_{6} \mathrm{O}_{2}$ & 1.21 & $68^{\circ} \mathrm{C}$ & $55-56^{\circ} \mathrm{C}$ \\
\hline $\begin{array}{l}\text { methyl-2- } \\
\text { thiopene } \\
\text { carboxylate }\end{array}$ & $\mathrm{C}_{7} \mathrm{H}_{8} \mathrm{O}_{2} \mathrm{~S}$ & 0.40 & $89^{\circ} \mathrm{C}$ & $218^{\circ} \mathrm{C}$ \\
\hline $\begin{array}{l}5 \text { methyl } \\
\text { furfural }\end{array}$ & $\mathrm{C}_{6} \mathrm{H}_{6} \mathrm{O}_{2}$ & 0.70 & $72^{\circ} \mathrm{C}$ & $187^{\circ} \mathrm{C}$ \\
\hline $\begin{array}{l}\text { 2-butanone, } \\
\text { 3,3-dimethyl- }\end{array}$ & $\mathrm{C}_{6} \mathrm{H}_{12} \mathrm{O}$ & 0.45 & $5^{\circ} \mathrm{C}$ & $\begin{array}{l}103 \text { to } \\
106^{\circ} \mathrm{C}\end{array}$ \\
\hline $\begin{array}{l}\text { 2-cyclopenten- } \\
\text { 1-one, 3- } \\
\text { methyl }\end{array}$ & $\mathrm{C}_{6} \mathrm{H}_{8} \mathrm{O}$ & 0.84 & $49^{\circ} \mathrm{C}$ & $\begin{array}{l}158- \\
161^{\circ} \mathrm{C}\end{array}$ \\
\hline phenol & $\mathrm{C}_{6} \mathrm{H}_{6} \mathrm{O}$ & 0.43 & $79^{\circ} \mathrm{C}$ & $182^{\circ} \mathrm{C}$ \\
\hline $\begin{array}{l}\text { phenol } \\
\text { propanoic }\end{array}$ & $\mathrm{C}_{6} \mathrm{H}_{6} \mathrm{O}$ & 3.38 & $79^{\circ} \mathrm{C}$ & $182^{\circ} \mathrm{C}$ \\
\hline $\begin{array}{l}\text { acid, 2-methyl- } \\
\text {, anhydride } \\
\text { 2-cyclopenten- }\end{array}$ & $\mathrm{C}_{8} \mathrm{H}_{14} \mathrm{O}_{3}$ & 0.85 & 66 & $182^{\circ}$ \\
\hline $\begin{array}{c}\text { 1-one, } 2- \\
\text { hydroxy-3- } \\
\text { methyl- }\end{array}$ & $\mathrm{C}_{6} \mathrm{H}_{8} \mathrm{O}_{2}$ & 4.88 & $100.7^{\circ} \mathrm{C}$ & $245.2^{\circ} \mathrm{C}$ \\
\hline $\begin{array}{l}\text { phenol, 2- } \\
\text { methyl }\end{array}$ & $\mathrm{C}_{7} \mathrm{H}_{8} \mathrm{O}$ & 0.66 & $81^{\circ} \mathrm{C}$ & $191^{\circ} \mathrm{C}$ \\
\hline $\begin{array}{l}\text { phenol, 2- } \\
\text { methyl }\end{array}$ & $\mathrm{C}_{7} \mathrm{H}_{8} \mathrm{O}$ & 1.20 & $81^{\circ} \mathrm{C}$ & $191^{\circ} \mathrm{C}$ \\
\hline $\begin{array}{l}\text { phenol, 3- } \\
\text { methyl- }\end{array}$ & $\mathrm{C}_{7} \mathrm{H}_{8} \mathrm{O}$ & 0.28 & $86^{\circ} \mathrm{C}$ & $203^{\circ} \mathrm{C}$ \\
\hline $\begin{array}{l}\text { phenol, 3- } \\
\text { methyl- }\end{array}$ & $\mathrm{C}_{7} \mathrm{H}_{8} \mathrm{O}$ & 4.54 & $86^{\circ} \mathrm{C}$ & $203^{\circ} \mathrm{C}$ \\
\hline $\begin{array}{l}\text { phenol, 2- } \\
\text { methoxy- }\end{array}$ & $\mathrm{C}_{7} \mathrm{H}_{8} \mathrm{O}_{2}$ & 1.32 & $82{ }^{\circ} \mathrm{C}$ & $205^{\circ} \mathrm{C}$ \\
\hline pentanal & $\mathrm{C}_{5} \mathrm{H}_{10} \mathrm{O}$ & 0.83 & $12^{\circ} \mathrm{C}$ & $\begin{array}{l}102 \text { to } \\
103^{\circ} \mathrm{C}\end{array}$ \\
\hline
\end{tabular}

\begin{tabular}{|c|c|c|c|c|}
\hline & & & & \\
\hline $\begin{array}{l}\text { 2-cyclopenten- } \\
\text { 1-one, 3-ethyl- } \\
\text { 2-hydroxy- }\end{array}$ & $\mathrm{C}_{7} \mathrm{H}_{10} \mathrm{O}_{2}$ & 0.81 & $107^{\circ} \mathrm{C}$ & \\
\hline $\begin{array}{c}\text { phenol, } 2,4- \\
\text { dimethyl- }\end{array}$ & $\mathrm{C}_{8} \mathrm{H}_{10} \mathrm{O}$ & 0.28 & $94^{\circ} \mathrm{C}$ & $\begin{array}{l}211- \\
212^{\circ} \mathrm{C}\end{array}$ \\
\hline $\begin{array}{l}\text { phenol, 2,4- } \\
\text { dimethyl- }\end{array}$ & $\mathrm{C}_{8} \mathrm{H}_{10} \mathrm{O}$ & 0.46 & $94^{\circ} \mathrm{C}$ & $\begin{array}{l}211- \\
212^{\circ} \mathrm{C}\end{array}$ \\
\hline $\begin{array}{l}\text { phenol, 3,4- } \\
\text { dimethyl- }\end{array}$ & $\mathrm{C}_{8} \mathrm{H}_{10} \mathrm{O}$ & 1.08 & $61^{\circ} \mathrm{C}$ & $227^{\circ} \mathrm{C}$ \\
\hline $\begin{array}{l}\text { phenol, 2,3- } \\
\text { dimethyl- }\end{array}$ & $\mathrm{C}_{8} \mathrm{H}_{10} \mathrm{O}$ & 0.30 & $95^{\circ} \mathrm{C}$ & $217^{\circ} \mathrm{C}$ \\
\hline $\begin{array}{l}\text { 2-methoxy-4- } \\
\text { methylphenol }\end{array}$ & $\mathrm{C}_{8} \mathrm{H}_{10} \mathrm{O}_{2}$ & 1.95 & $99^{\circ} \mathrm{C}$ & $\begin{array}{l}221- \\
222^{\circ} \mathrm{C}\end{array}$ \\
\hline $\begin{array}{c}1,2- \\
\text { benzenediol }\end{array}$ & $\mathrm{C}_{6} \mathrm{H}_{6} \mathrm{O}_{2}$ & 4.03 & $127^{\circ} \mathrm{C}$ & $245^{\circ} \mathrm{C}$ \\
\hline $\begin{array}{l}\text { phenol, 2- } \\
\text { ethoxy- }\end{array}$ & $\mathrm{C}_{8} \mathrm{H}_{10} \mathrm{O}_{2}$ & 0.29 & $91^{\circ} \mathrm{C}$ & $\begin{array}{l}216- \\
217^{\circ} \mathrm{C}\end{array}$ \\
\hline $\begin{array}{l}\text { benzeneethan } \\
\text { ol, 2-methoxy- }\end{array}$ & $\mathrm{C}_{9} \mathrm{H}_{12} \mathrm{O}_{2}$ & 1.38 & $113^{\circ} \mathrm{C}$ & $\begin{array}{l}133^{-} \\
135^{\circ} \mathrm{C}\end{array}$ \\
\hline $\begin{array}{l}\text { 2-methoxy-4- } \\
\text { vinylphenol }\end{array}$ & $\mathrm{C}_{9} \mathrm{H}_{10} \mathrm{O}_{2}$ & 0.48 & $113^{\circ} \mathrm{C}$ & $224^{\circ} \mathrm{C}$ \\
\hline $\begin{array}{l}\text { phenol, 2,6- } \\
\text { dimethoxy- }\end{array}$ & $\mathrm{C}_{8} \mathrm{H}_{10} \mathrm{O}_{3}$ & 7.43 & $140^{\circ} \mathrm{C}$ & $261^{\circ} \mathrm{C}$ \\
\hline $\begin{array}{l}\text { benzenaldehy } \\
\text { de, 4-hydroxy- } \\
\text { 3-methoxy }\end{array}$ & $\mathrm{C}_{8} \mathrm{H}_{8} \mathrm{O}_{3}$ & 0.63 & $147^{\circ} \mathrm{C}$ & $285^{\circ} \mathrm{C}$ \\
\hline vanillic acid & $\mathrm{C}_{8} \mathrm{H}_{8} \mathrm{O}_{4}$ & 5.09 & $149.4 \stackrel{\circ}{ } \mathrm{C}$ & $353.4 \stackrel{\circ}{\circ} \mathrm{C}$ \\
\hline Acetovanillone & $\mathrm{C}_{9} \mathrm{H}_{10} \mathrm{O}_{3}$ & 0.53 & $125.5^{\circ} \mathrm{C}$ & $297.5^{\circ} \mathrm{C}$ \\
\hline $\begin{array}{c}2,3,5- \\
\text { trimethoxytolu } \\
\text { ene }\end{array}$ & $\mathrm{C}_{10} \mathrm{H}_{14} \mathrm{O}_{3}$ & 3.50 & $74^{\circ} \mathrm{C}$ & $\begin{array}{l}117- \\
118^{\circ} \mathrm{C}\end{array}$ \\
\hline $\begin{array}{c}\text { phenol, 2- } \\
\text { methoxy-4- } \\
\text { propyl- }\end{array}$ & $\mathrm{C}_{10} \mathrm{H}_{14} \mathrm{O}_{2}$ & 0.98 & $110^{\circ} \mathrm{C}$ & $\begin{array}{l}125- \\
126^{\circ} \mathrm{C}\end{array}$ \\
\hline $\begin{array}{l}\text { 2,6-dimethyl- } \\
\text { p- }\end{array}$ & $\mathrm{C}_{8} \mathrm{H}_{8} \mathrm{O}_{2}$ & 1.08 & $71^{\circ} \mathrm{C}$ & $201^{\circ} \mathrm{C}$ \\
\hline $\begin{array}{l}\text { benzoquinon } \\
\text { phenol, 2,6- } \\
\text { dimethoxy-4- } \\
\text { (2propenyl)- }\end{array}$ & $\mathrm{C}_{11} \mathrm{H}_{14} \mathrm{O}_{3}$ & 0.44 & $136.1^{\circ} \mathrm{C}$ & $301.4^{\circ} \mathrm{C}$ \\
\hline $\begin{array}{l}2(1 \mathrm{~h})- \\
\text { pyrimidinone }\end{array}$ & $\mathrm{C}_{5} \mathrm{H}_{5} \mathrm{NO}$ & 0.46 & $210^{\circ} \mathrm{C}$ & $\begin{array}{l}280- \\
281^{\circ} \mathrm{C}\end{array}$ \\
\hline $\begin{array}{l}\text { phenol, , 6- } \\
\text { dimethoxy-4- } \\
\text { (2propenyl)- }\end{array}$ & $\mathrm{C}_{11} \mathrm{H}_{14} \mathrm{O}_{3}$ & 0.47 & $136.1^{\circ} \mathrm{C}$ & $301.4^{\circ} \mathrm{C}$ \\
\hline $\begin{array}{l}\text { benzenaldehy } \\
\text { de, 4-hydroxy- } \\
\text { 3,5-dimethoxy }\end{array}$ & $\mathrm{C}_{9} \mathrm{H}_{10} \mathrm{O}_{4}$ & 0.49 & $110^{\circ} \mathrm{C}$ & $\begin{array}{l}192 \text { to } \\
193^{\circ} \mathrm{C}\end{array}$ \\
\hline $\begin{array}{l}\text { phenol, 2,6- } \\
\text { dimethoxy-4- } \\
\text { (2propenyl)- }\end{array}$ & $\mathrm{C}_{11} \mathrm{H}_{14} \mathrm{O}_{3}$ & 1.02 & $136.1^{\circ} \mathrm{C}$ & $301.4^{\circ} \mathrm{C}$ \\
\hline acetophenone & $\mathrm{C}_{8} \mathrm{H}_{8} \mathrm{O}$ & 0.82 & $82^{\circ} \mathrm{C}$ & $202^{\circ} \mathrm{C}$ \\
\hline $\begin{array}{c}\text { butyrophenon } \\
\mathrm{e}\end{array}$ & $\mathrm{C}_{10} \mathrm{H}_{12} \mathrm{O}$ & 2.02 & $88^{\circ} \mathrm{C}$ & $\begin{array}{l}228- \\
230^{\circ} \mathrm{C}\end{array}$ \\
\hline
\end{tabular}

Selanjutnya, hasil dari GC-MS juga akan didapatkan informasi berupa flammable matter (senyawa yang mudah terbakar), yang terdiri dari beberapa senyawa termasuk asam asetat,yang dapat dilihat pada grafik 4 . Pada temperatur $250^{\circ} \mathrm{C}$ mengandung senyawa yang mudah terbakar yaitu sebesar $55.10 \%$ dan senyawa tidak mudah terbakar sebesar $44.91 \%$. Pada temperatur $350^{\circ} \mathrm{C}$ senyawa yang mudah terbakar yaitu sebesar $78.23 \%$ dan senyawa tidak mudah terbakar sebesar $21.27 \%$. Pada temperatur $450^{\circ} \mathrm{C}$ senyawa yang mudah terbakar yaitu sebesar $69.87 \%$ dan senyawa tidak mudah terbakar sebesar $30.11 \%$. Pada temperatur $500^{\circ} \mathrm{C}$ senyawa yang mudah terbakar yaitu sebesar $63.65 \%$ dan senyawa tidak mudah terbakar sebesar $36.44 \%$. Pada temperatur $600^{\circ} \mathrm{C}$ senyawa yang mudah terbakar yaitu sebesar $78.28 \%$ 
dan senyawa tidak mudah terbakar sebesar $21.72 \%$. Pada temperatur $700^{\circ} \mathrm{C}$ senyawa yang mudah terbakar yaitu sebesar $63.65 \%$ dan senyawa tidak mudah terbakar sebesar $36.43 \%$. Dan Pada temperatur $800^{\circ} \mathrm{C}$ senyawa yang mudah terbakar yaitu sebesar $60.56 \%$ dan senyawa tidak mudah terbakar sebesar $39.44 \%$.

Dari hasil keseluruhan pada setiap variasi temperatur didapatkan bahwa pada temperatur $600^{\circ} \mathrm{C}$, tar mempunyai kandungan senyawa yang mudah terbakar dengan presentase paling tinggi. Hal ini dikarenakan presentase mayoritas senyawa asam asetat yang cukup besar yaitu sebesar $17.14 \%$, dimana diketahui bahwa asam asetat merupakan penyusun utama sebagai senyawa yang termasuk mudah terbakar dengan titik nyala $39^{\circ} \mathrm{C}$ dan sebab lainnya yaitu dikarenakan banyaknya senyawa minoritas pada temperatur $600^{\circ} \mathrm{C}$ yang juga memiliki karakteristik dengan titik nyala kurang dari $93^{\circ} \mathrm{C}$, sehingga dapat digolongkan menjadi senyawa yang mudah terbakar [10].

Secara umum, hasil penelitian menunjukkan bahwa peningkatan temperatur pirolisis menyebabkan volume dan masa tar yang terbentuk akibat kondensasi pada cold trapakan mengalami peningkatan produksi sampai titik puncaknya pada temperatur pirolisis $500^{\circ} \mathrm{C}$. Setelah itu, seiring dengan peningkatan temperatur hingga $800^{\circ} \mathrm{C}$, volume dan masa tar mengalami penurunan. Penurunan tar ini disebabkan karena ikatan-ikatan molekul tar yang lebih panjang terdekomposisi menjadi lebih pendek, yaitu menjadi gas. Secara umum, pada berbagai variasi temperatur pirolisis, tar mayoritas didominasi oleh senyawa asam asetat dan senyawa minoritas seperti furfural dan fenol.

Peningkatan temperatur juga akan meningkatkan produk tar berupa senyawa asam asetat yang meningkat sampai pada temperatur pirolisis $350^{\circ} \mathrm{C}$. Setelah itu, terjadi penurunan produksi asam asetat hingga temperatur $800^{\circ} \mathrm{C}$. $\mathrm{Hal}$ ini dikarenakan penyusun senyawa asam asetat seperti selulosa dan hemiselulosa mengalami dekomposisi maksimal pada temperatur $350^{\circ} \mathrm{C}$.Selanjutnya, identifikasi senyawa tar dapat dibagi dalam kelompok senyawa flammable dan non-flammable yaitu senyawa yang mudah terbakar dan tidak mudah terbakar.Pengelompokan ini dilihat berdasarkan titik nyala senyawanya.Senyawa yang mudah terbakar adalah senyawa yang memiliki titik nyala antara $60^{\circ} \mathrm{C}$ hingga $93^{\circ} \mathrm{C}$.

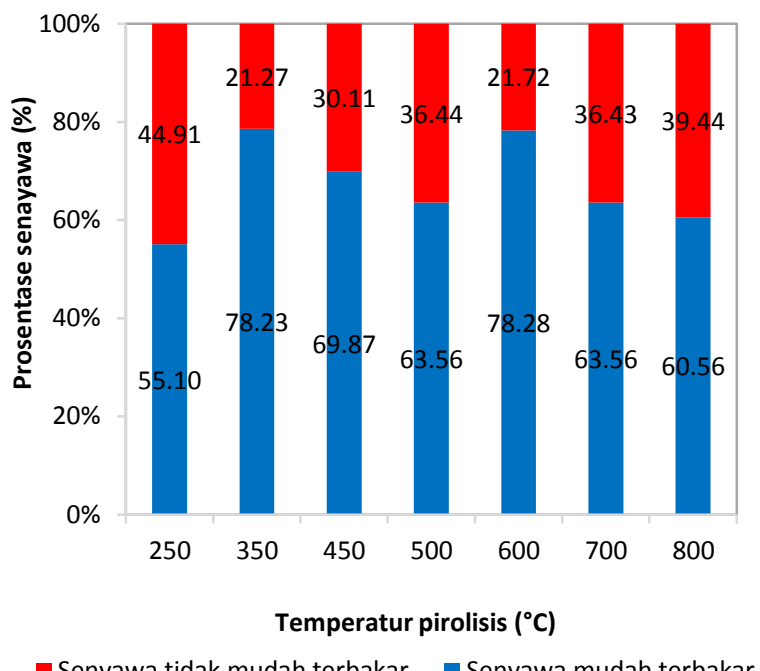

Gambar 4. Grafik pengaruh temperatur pirolisis terhadap presentase senyawa tar yang mudah terbakar dan senyawa tar yang tidak mudah terbakar.

Hasil penelitian menunjukkan bahwa pada setiap temperatur pirolisis, jumlah senyawa tar yang mudah terbakar lebih banyak (tinggi) dibanding senyawa tar yang tidak mudah terbakar, Penyebabnya ternyata karena penyusun utama tar mayoritas adalah asam asetat dengan titik nyalanya $39^{\circ} \mathrm{C}$ yang dapat digolongkan sebagai senyawa yang mudah terbakar dan hal ini juga didukung dengan banyaknya senyawa minoritas yang juga memiliki sifat mampu bakar dengan karakteristik titik nyala $<93^{\circ} \mathrm{C}$.

\section{KESIMPULAN}

Dari hasil penelitian dan analisa grafik serta pembahasan, maka dapat disimpulkan bahwa :

Semakin tinggi temperatur pirolisis maka volume tar yang dihasilkan akan semakin meningkat sampai titik maksimum pada temperatur $500^{\circ} \mathrm{C}$ dan kemudian menurun sampai temperatur $800^{\circ} \mathrm{C}$. Penurunan tar ini dikarenakan pada temperatur lebih dari $500^{\circ} \mathrm{C}$, condensable gas akan terdekomposisi menjadi molekul lebih sederhana yang berupa non condensable gas. 
Semakin tinggi temperatur pirolisis maka presentase kandungan asam asetat akan semakin meningkat sampai titik maksimum pada temperatur 350 oC dan kemudian turun sampai temperatur $8000 \mathrm{C}$. Hal ini dikarenakan penyusun senyawa asam asetat seperti selulosa dan hemiselulosa sudah mengalami dekomposisi secara maksimalpada temperatur $350^{\circ} \mathrm{C}$.

Secara umum presentase kandungan senyawa tar yang mudah terbakar dan senyawa yang tidak mudah terbakar pada setiap variasi temperatur pirolisis, menunjukkan bahwa kandungan senyawa yang mudah terbakar memiliki presentase paling besar dibandingkan dengan senyawa yang tidak mudah terbakar.

\section{DAFTAR PUSTAKA}

[1] Outlook Energy Indonesia, 2014, Energi masadepan di sektor transportasi dan kelistrikan. Pusat Teknologi Pengembangan Sumber Daya dan Energi.BBPT.BPPYPress. Jakarta

[2] Yu, Haimiao, Zhang, Ze, Li, Zeshen. \& Chen, Dezhen, 2013, Characteristics Of Tar Formation During Cellulose, Hemicellulose, And Lignin Gasification. Tongji University, China

[3] Yorgun, Sait. \& Yildiz, Derya, 2015, Slow Pyrolysis Of Paulownia Wood: Effects Of Pyrolysis Parameters On Product Yield And Bio-Oil Characterization. Turkey

[4] XiaoxiaoYang et al, A modified kinetic analysis method of cellulose pyrolysis based on TG-FTIR technique, Thermochimica Acta Volume 665, 10 July 2018, Pages 2027

[5] Zhezi Zhang, et. Al., A Thermogravimetric study of the characteristics of pyrolysis of cellulose isolated from selected biomass, Applied Energy Volume 220, 15 June 2018, Pages 87-93

[6] Singh, S.P., 2009, Biodiesel production through the use of different sources ancharacterization of oils and their esters as the substitute of diesel: A review. Devi Ahilya University, India
[7] Sunarsih, S., Pratiwi Y., \& Sunarto, Y., 2012, Pengaruh suhu, waktu dan kadar air pada pembuatan asap cair dari limbah padat pati aren (studi kasus pada sentra industri sohun Dukuh Bendo, Daleman, Tulung, Klaten). Fakultas Sains Terapan, IST Akprind Yogyakarta

[8] Akbar, A., Paindonan, W., Coniwanti, P., 2013, Pengaruh variabel waktu dan temperatur terhadap pembuatan asap cair dari limbah kayu pelawan (cynometra cauliflora), Jurusan Teknik Kimia Fakultas Teknik Universitas Sriwijaya

[9] Qian, K., \& Kumar, A., 2015, Reforming of lignin-derived tars over char-based catalystusing Py-GC/MS. Oklahoma State University, Stillwater, OK, United States

[10] Prastyanto, B.J, \& Sudarmanta, B., 2012, Pengaruh Penambahan Biodiesel Dari Minyak Biji Nyamplung (C. Inophyllum) Pada Bahan Bakar Solar Terhadap Hasil Uji Unjuk Kerja Mesin Diesel Generator Set. Jurusan Teknik Mesin, Fakultas Teknologi Industri, Institut Teknologi Sepuluh Nopember (ITS).

[11] Pohanish, R.P., 2014, Sittig's Handbook of Pesticidies agricultural chemical, Elsevier

[12] Lopez, D., Acelas, N., \& Mondragon, F., 2019, Average structural analysis of tar obtained from pyrolisis of wood. Colombia

[13] Wibowo, santiyo, 2013, Characteristic Of Bio-Oil From Sengon (Paraserianthes Falcataria L. Nielsen) Sawdust By Slow Pyrolysis Process. Vol. 31 No. 4, 2013 : 258-270

[14] Jahirul, M.I., Rasul, M.G., Chowdhury, A.A. \& Ashwath, N., 2004, Biofuels Production Through Biomass Pyrolisis - A tecnological Review: Queensland University of Technology, Brisbane, Australia

[15] Widya Wijayanti \& Ken-Ichiro Tanoue, 2013, Char Formation and Gas Products of Woody Biomass Pyrolysis, Energy Procedia, Vol. 32, pp 145-152 